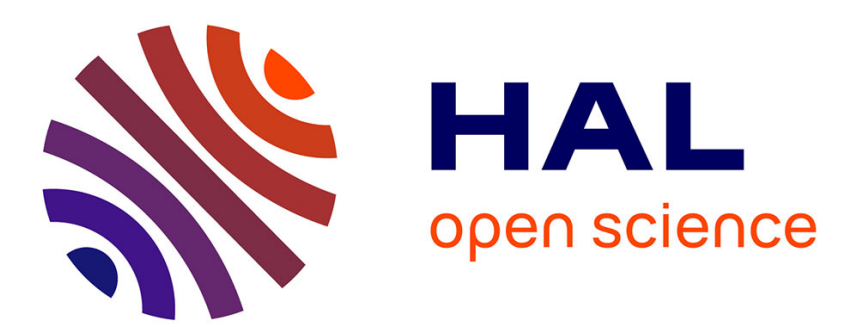

\title{
Measurement of stratosphere-to-troposphere exchange in Antarctica by using short-lived cosmonuclides
}

\author{
J. Sanak, G. Lambert, B. Ardouin
}

\section{To cite this version:}

J. Sanak, G. Lambert, B. Ardouin. Measurement of stratosphere-to-troposphere exchange in Antarctica by using short-lived cosmonuclides. Tellus B - Chemical and Physical Meteorology, 1985, 37 (2), pp.109-115. 10.3402/tellusb.v37i2.15005 . hal-03520442

\section{HAL Id: hal-03520442 \\ https://hal.science/hal-03520442}

Submitted on 11 Jan 2022

HAL is a multi-disciplinary open access archive for the deposit and dissemination of scientific research documents, whether they are published or not. The documents may come from teaching and research institutions in France or abroad, or from public or private research centers.
L'archive ouverte pluridisciplinaire HAL, est destinée au dépôt et à la diffusion de documents scientifiques de niveau recherche, publiés ou non, émanant des établissements d'enseignement et de recherche français ou étrangers, des laboratoires publics ou privés. 


\section{Tellus B: Chemical and Physical Meteorology}

\section{Measurement of stratosphere-to-troposphere exchange in Antarctica by using short-lived cosmonuclides}

\section{J. Sanak, G. Lambert \& B. Ardouin}

To cite this article: J. Sanak, G. Lambert \& B. Ardouin (1985) Measurement of stratosphere-totroposphere exchange in Antarctica by using short-lived cosmonuclides, Tellus B: Chemical and Physical Meteorology, 37:2, 109-115, DOI: 10.3402/tellusb.v37i2.15005

To link to this article: https://doi.org/10.3402/tellusb.v37i2.15005

\section{(c) 1985 The Author(s). Published by Taylor \&} Francis.

\section{Published online: 18 Jan 2017.}

Submit your article to this journal $[\pi$

Џlll Article views: 153

Q View related articles $\sqsubset$

Citing articles: 1 View citing articles ¿ 


\title{
Measurement of stratosphere-to-troposphere exchange in Antarctica by using short-lived cosmonuclides
}

\author{
By J. SANAK, G. LAMBERT and B. ARDOUIN, Centre des Faibles Radioactivites, Laboratoire \\ mixte CNRS-CEA, Domaine du CNRS, 91190 Gif sur Yvette, France
}

(Manuscript received July 31: in final form November 19.1984)

\begin{abstract}
We have monitored the atmospheric concentrations of Be-7 and P. 32 at the French Antarctic station "Dumont d"Urville" from 1977 to 1981. The results show that the mean monthly value of the air flux exchanged between stratosphere and troposphere is particularly high close to Antarctica. reaching up to $60 \mathrm{~kg} \mathrm{~m}^{-2}$ day $^{-1}$.
\end{abstract}

\section{Introduction}

The latitudinal distributions of fission products and $\mathrm{Pb}-210$ at sea level, show generally a small but well-marked increase close to the Antarctic coast, as pointed out by Lambert et al. (1965) and Sanak (1983). This result could be accounted for by the existence of a stratospheric component particularly important for these nuclides over the Antarctic continent. With the aim of evaluating the stratosphere to troposphere exchange at polar latitudes, we have monitored the atmospheric concentrations of $\mathrm{Be}-7$ and $\mathrm{P}-32$ at the French Antarctic station "Dumont d'Urville" $\left(66^{\circ} 40^{\prime} \mathrm{S}\right.$, $140^{\circ} 01^{\prime}$ E) from 1977 to 1981 (Fig. 1). Both these nuclides are simultaneously produced in the atmosphere by interaction of secondary cosmic rays (neutrons and protons) with nitrogen. oxygen and argon nuclei. Lal and Peters $(1962,1967)$ were the first to propose their use as atmospheric tracers. They have shown that their production rates are increasing from ground level to the tropopause (from about 0.05 to 10 nuclei $\mathrm{min}^{-1} \mathrm{~kg}^{-a i r}{ }^{-1}$ for Be-7). Further up, in the stratosphere, they are slightly decreasing with altitude at tropical latitudes but they are still strongly increasing at polar latitudes (up to 80 nuclei min $^{-1} \mathrm{~kg}^{-a^{-1}}{ }^{-1}$ at $25 \mathrm{~km}$ for $\mathrm{Be}-7)$. The ratio of their production rates is constant everywhere $(B e-7 / \mathrm{P}-32=100)$. In spite of the solar activity variations, these production rates seem to be rather constant in the atmosphere. except at very high altitudes.

The Be-7 and P-32 atmospheric concentrations must result from an equilibrium between their production, their transport. their radioactive decay and the scavenging of the aerosols on which they are stuck. Therefore, studies of actual equilibrium can provide information about all of these atmospheric processes. The atmospheric concentrations of $\mathrm{Be}-7$ have been measured by a large number of authors at different places, including the stratosphere (Bhandari et al., 1966; Marenco, 1974; Feely et al., 1980; Reiter et al., 1983). Data concerning P-32 are more seldom and essentially relative to ground level (Marenco, 1974). The comparison of the atmospheric concentrations of both nuclides in the northern hemisphere was often disappointing since the origin of the studied aerosols was always difficult to establish. The situation is clearly different in Antarctic areas, owing to the weakness of the meridional exchanges in the subantarctic troposphere. Therefore it has been possible to use data obtained at Dumont d'Urville in a simple box model.

\section{Experimental procedure and results}

A high volume turbine sucked the air, sampled at about $40 \mathrm{~m}$ above sea level, through a fiber glass 


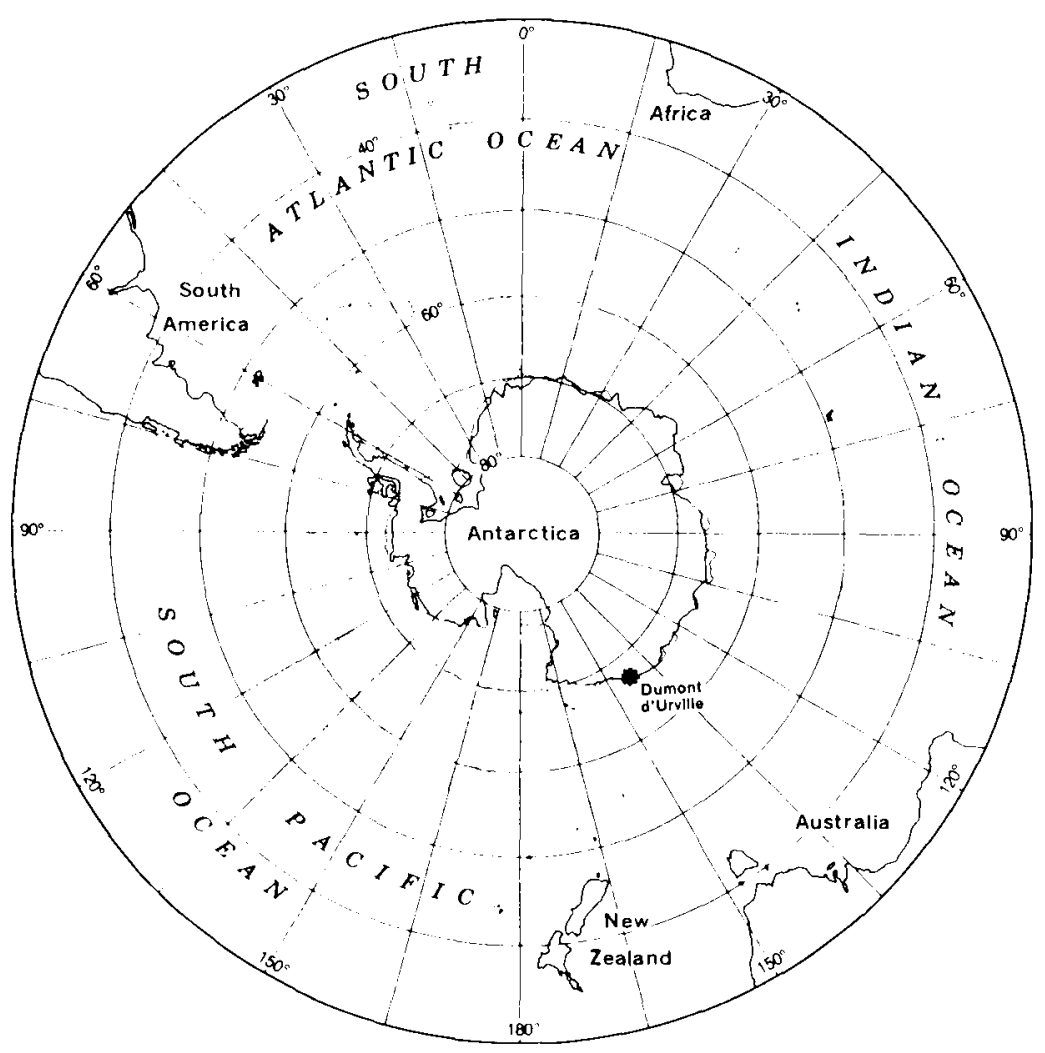

Fig. 1. Dumont d'Urville location on the Antarctic Continent.

filter (Whatmann GF/A) with a well-controlled flow rate of about $80 \mathrm{SCM} / \mathrm{h}$, over $24 \mathrm{~h}$. Aerosols collected on the filter were kept quiet during 3 days to allow the Rn-222 daughters' radioactivity to decay. The Be- $7 \gamma$ activity $(0.477 \mathrm{MeV})$ was then measured with a $3^{\prime \prime} \times 3^{\prime \prime} \mathrm{NaI}(\mathrm{T} 1)$ crystal detector followed by a multichannel analyser. The efficiency of the detector was 0.23 and the counting time was approximately $15 \mathrm{~h}$. Be-7 daily mean concentrations were measured from March 1977 to May 1981.

After the Be-7 measurement, the aerosols were dissolved in a concentrated sodium hydroxide solution with a phosphate carrier. P-32 atoms were then extracted as ammonium phosphomolybdate then as magnesium pyrophosphate. The $\mathrm{P}-32 \beta$ activity $(1.73 \mathrm{MeV})$ was measured with a solid state detector whose background was about 2.5 counts per minute, and the efficiency 0.30 . The counting time was typically $14 \mathrm{~h}$. Daily mean P-32 con- centrations were measured from January 1978 to April 1981, but unfortunately with interruptions due to detector failures. Details of these procedures have been described elsewhere (Sanak, 1983).

Typical daily mean values of the Be-7 and P-32 atmospheric concentrations are shown in Fig. 2 for 1978. They vary very sharply from day to day, from 0 to 1.1 dis $\min ^{-1 / S C M}$ for Be-7 and from 0 to $0.016 \mathrm{dis} \mathrm{min}^{-1} / \mathrm{SCM}$ for P-32. It does not seem that these variations can be related to local meteorological conditions. More particularly, no correlations are observed between $\mathrm{Be}-7$ or P-32 concentrations and atmospheric pressure or temperature, nor katabatic winds. However, most of the very low concentrations are observed during snow precipitations (but the reciprocal is not true). Finally, the only local meteorological parameter which seems to play a rôle is the existence of a temperature-inversion layer, especially in winter.

Most of the concentrations measured are by far 


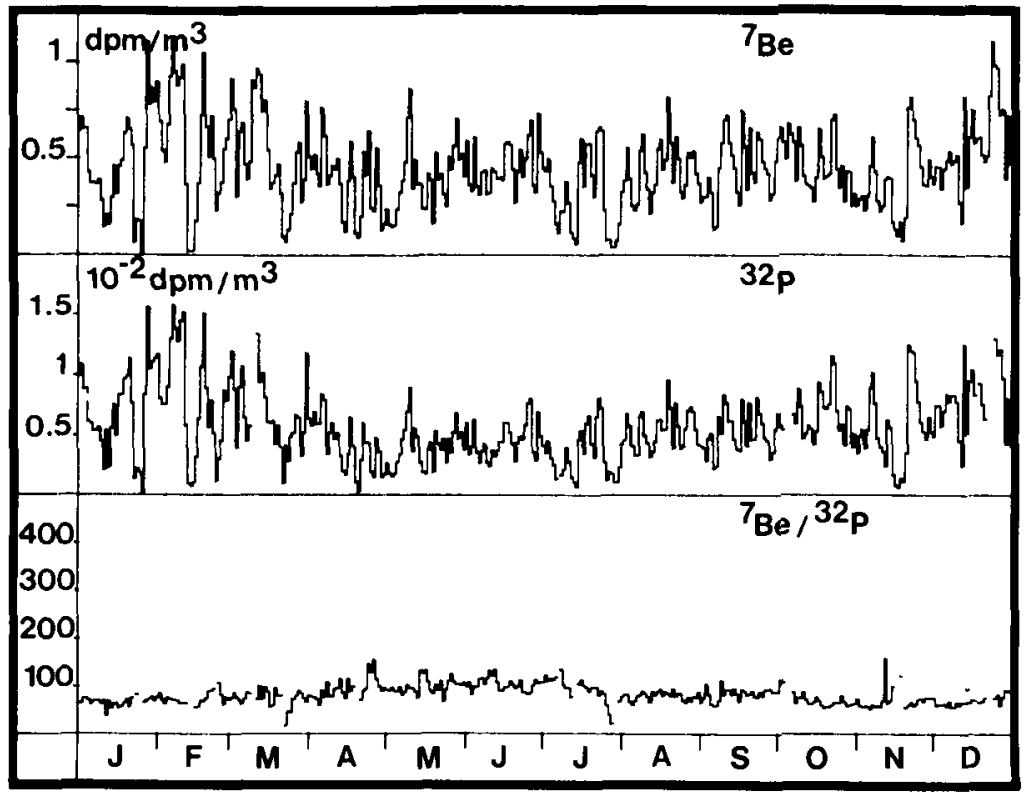

Fig. 2. Typical daily mean activity of $B e-7$ and $P-32$ and activity ratio Be-7/P-32.

higher than the maximum accounted for by the local production near the ground. In effect, in the lack of vertical motions and taking into account the scavenging processes, the specific activity at ground level should be smaller than the local production rates for each of these nuclides (i.e., about 0.05 and 0.0005 nuclei $\mathrm{min}^{-1} / \mathrm{SCM}$ for $\mathrm{Be}-7$ and P-32, respectively). For instance, with aerosol scavenging time of 7 days, as commonly accepted, the mean Be-7 activity should be about 0.004 dis $\mathrm{min}^{-1} / \mathrm{SCM}$, and the mean activity of P-32 0.00013 dis $\min ^{-1} / \mathrm{SCM}$. A large part of the cosmonuclides sampled at ground level are therefore likely to have been contributed from upper layers of the atmosphere where the production rate is higher, although, in no case, are the observed concentrations high enough to be undoubtedly characteristic of the lower stratosphere.

However, variations of the mean monthly values of the concentrations of these cosmonuclides appear to be rather small, from 0.29 to 0.58 dis $\mathrm{min}^{-1} / \mathrm{SCM}$ for Be-7 and from 0.0022 to 0.0080 dis $\min ^{-1} / \mathrm{SCM}$ for P-32 (Table 1). This means that one month is a rather long time compared to all of the time constants involved in the tropospheric mixing and scavenging processes. Particularly,
Dumont d'Urville is located on the Antarctic coast in a zone where powerful storms stir up the troposphere all around the Antarctic continent. A fairly good mixing may be assumed to take place and, consequently, the air analysed during one month can give a good estimation of the overall mean concentrations in the whole troposphere around the Antarctic continent.

\section{Be-7 and P-32 in the Antarctic troposphere}

The preceding results can be tentatively interpreted with the following remarks and assumptions. Synoptic studies (Trenberth, 1981), and Rn-222 atmospheric concentrations (Polian, 1984 ) indicate that meridional air circulation towards Antarctica is generally rather weak. Therefore, as Be-7 and P-32 tropospheric production rates do not vary significantly with latitude (at least from the Pole to about $40^{\circ} \mathrm{S}$ ), the meridional circulation of these cosmonuclides can be neglected. Moreover, it is worthwhile to note that continental air masses advections to the coastal station would be characterized by high

Tellus 37B (1985), 2 
Table 1. Stratosphere to troposphere exchange and residence time of Be-7 and P-32 over Antarctica: (1) dis min $1 / S C M$; (2) $\mathrm{kg} \mathrm{m}^{2}{\text { da } \mathrm{y}^{-2}}^{-2}$

\begin{tabular}{|c|c|c|c|c|c|c|c|c|}
\hline \multirow{2}{*}{\multicolumn{2}{|c|}{ Date }} & \multicolumn{2}{|c|}{ Activity (1) } & \multirow{2}{*}{$\begin{array}{l}\text { Troposphere } \\
\text { height } \\
\text { (m) }\end{array}$} & \multirow{2}{*}{$\begin{array}{l}\text { Air flux } \\
\text { (2) }\end{array}$} & \multirow{2}{*}{$\begin{array}{l}\text { Scavenging } \\
\text { time } \\
\text { (day) }\end{array}$} & \multicolumn{2}{|c|}{$\begin{array}{l}\text { Stratospheric } \\
\text { fraction }\end{array}$} \\
\hline & & $\mathrm{Be}-7$ & P-32 & & & & $\mathrm{Be}-7$ & P-32 \\
\hline \multirow[t]{12}{*}{1978} & $1^{*}$ & 0.47 & 0.0069 & 8.690 & $47^{*}$ & $7.4^{*}$ & 0.70 & 0.38 \\
\hline & $2^{*}$ & 0.58 & 0.0080 & 8,850 & $60^{*}$ & $7.6^{*}$ & 0.74 & 0.44 \\
\hline & 3 & 0.53 & 0.0067 & 8.350 & 98 & 5.2 & & \\
\hline & 4 & 0.38 & 0.0042 & 8.410 & 417 & 0.9 & & \\
\hline & 5 & 0.39 & 0.0040 & 8.770 & 2.812 & 0.1 & & \\
\hline & 6 & 0.45 & 0.0045 & 9,710 & $-4,084$ & -0.1 & & \\
\hline & 7 & 0.31 & 0.0033 & 9.850 & 625 & 0.4 & & \\
\hline & 8 & 0.44 & 0.0054 & 9.500 & 155 & 2.1 & & \\
\hline & 9 & 0.44 & 0.0052 & 9,330 & 232 & 1.5 & & \\
\hline & 10 & 0.48 & 0.0066 & 9,120 & 74 & 4.8 & & \\
\hline & $11^{*}$ & 0.37 & 0.0056 & 8.230 & $53^{*}$ & $6.0^{*}$ & 0.72 & 0.41 \\
\hline & $12^{*}$ & 0.58 & 0.0078 & 8.590 & $61^{*}$ & $8.0^{*}$ & 0.75 & 0.44 \\
\hline \multirow[t]{5}{*}{1979} & $1^{*}$ & 0.42 & 0.0062 & 8,790 & $57^{*}$ & $5.5^{*}$ & 0.74 & 0.43 \\
\hline & $2^{*}$ & 0.45 & 0.0078 & 8.430 & $17^{*}$ & $14.3^{*}$ & 0.46 & 0.19 \\
\hline & $3^{*}$ & 0.38 & 0.0064 & 8,530 & $28^{*}$ & $8.6^{*}$ & 0.58 & 0.27 \\
\hline & $4^{*}$ & 0.48 & 0.0069 & 8,360 & $51^{*}$ & $7.8^{*}$ & 0.71 & 0.40 \\
\hline & 5 & 0.40 & 0.0054 & 9.060 & 93 & 3.3 & & \\
\hline \multirow[t]{9}{*}{1980} & 4 & 0.46 & 0.0070 & 9.180 & 47 & 6.4 & & \\
\hline & 5 & 0.34 & 0.0043 & 8.690 & 146 & 2.1 & & \\
\hline & 6 & 0.29 & 0.0022 & 9,200 & -219 & -1.3 & & \\
\hline & 7 & 0.30 & 0.0036 & 10.280 & 249 & 0.8 & & \\
\hline & 8 & 0.37 & 0.0043 & 10.790 & 284 & 0.8 & & \\
\hline & 9 & 0.33 & 0.0042 & 10.560 & 152 & 1.3 & & \\
\hline & $10^{*}$ & 0.30 & 0.0058 & 8.790 & $19^{*}$ & $7.8^{*}$ & 0.48 & 0.20 \\
\hline & $11^{*}$ & 0.35 & 0.0076 & 9,050 & $8^{*}$ & $12.7^{*}$ & 0.27 & 0.09 \\
\hline & $12^{*}$ & 0.34 & 0.0059 & 8.930 & $29^{*}$ & $6.7^{*}$ & 0.59 & 0.28 \\
\hline
\end{tabular}

Asterisks indicate the months when the meteorological conditions meet the model hypothesis.

cosmonuclide concentrations, due to the higher production rates at the altitude of the polar plateau. The seasonal shift of the polar vortex should then induce concentration increases in winter for both cosmonuclides. In fact, P-32 and. to a smaller extent, Be-7 concentrations show a maximum in summer which therefore cannot be explained by the above-mentioned mechanism. Consequently, at the latitude of our station, the troposphere can be considered as a box isolated from the rest of the atmosphere. and well-mixed from ground level up to the tropopause. Therefore, the only exchange to be considered here. occurs between this tropospheric box and the stratosphere above (Fig. 3).

For the above model, in a $1 \mathrm{~m}^{2}$ section tropospheric column, for each of the cosmo-

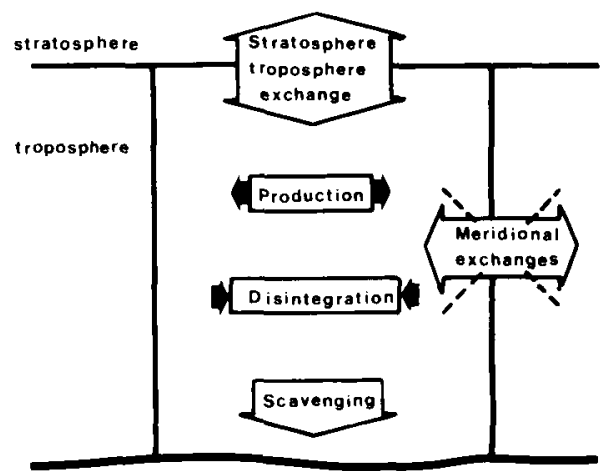

Fig. 3. Steady box model. Production $Q t r)+$ stratosphere to troposphere exchange $F C(\mathrm{st})=$ disintegration $\lambda C(\mathrm{tr}) M(\mathrm{tr})+$ scavenging $\lambda_{\mathrm{s}} C(\mathrm{tr}) M(\mathrm{tr})+$ troposphere to stratosphere exchange $F C(\mathrm{tr})$. 
nuclides, local production and stratospheric injections are balanced by radioactive disintegration and the scavenging processes according to the following equation:

$Q(\mathrm{tr})+F C(\mathrm{st})=\left(\lambda+\lambda_{\mathrm{s}}\right) C(\mathrm{tr}) M(\mathrm{tr})+F C(\mathrm{tr})$,

where $Q(\mathrm{tr})$ is the production rate (atom $\mathrm{m}^{-2}$ day ${ }^{-1}$ ) and $C(\mathrm{tr})$ the concentration (atom $\mathrm{kg}^{-1}$ ) of the cosmonuclide in the tropospheric box, $C($ st) its concentration (atom $\mathrm{kg}^{-1}$ ) in the lower stratosphere. $\lambda$ its radioactive decay constant, and $\lambda_{\mathrm{s}}$ the scavenging constant $\left(\mathrm{day}^{-1}\right)$ for submicronic aerosols and $F$ the air flux exchanged $\left(\mathrm{kg} \mathrm{m}^{-2}\right.$ day $^{-1}$ ) between the stratosphere and this tropospheric box. $M(\mathrm{tr})$ is the mass of the air $(\mathrm{kg}$ $\mathrm{m}^{-2}$ ) contained in a $1 \mathrm{~m}^{2}$ column of the tropospheric box. $M$ (tr) can be computed from the Standard US Atmosphere data by using a tropopause height deduced from local meteorological observations (from the French Weather Service "Meteorologie Nationale"). $C$ (st) is assumed to be equal to the production rate at the tropopause level. The coefficients $F$ and $\lambda_{\mathrm{s}}$ can therefore be computed by using, in eq. (1), the monthly mean concentrations of Be-7 and P-32 measured at Dumont d'Urville. The results are given in Table 1.

\section{Discussion and conclusion}

The results show two very different kinds of figures. In January and February 1978, then from November 1978 to April 1979 and from October to December 1980, the values of the air flow (about $40 \mathrm{~kg} \mathrm{~m}^{-2}$ day $\left.^{-1}\right)$ and the scavenging time $T_{\mathrm{s}}\left(T_{\mathrm{s}}=\right.$ $1 / \lambda_{\mathrm{s}}$, about 8.5 days) are quite reasonable. These results are indicated in Table 1 by a star.

On the other hand, during other months, the values computed are very different, and sometimes even aberrant. This difference could be accounted for by the existence of temperature surface inversions over Dumont d'Urville, during cold months, which prevent the ground level air from mixing with the free troposphere. Similar observations were made by Hogan et al. (1982) at the South Pole station. It may be checked that a temperature surface inversion over Dumont d'Urville is quite well-established near the ground in winter, when sea surface is ice-field covered. Fig. 4 shows the thickness of this layer and of the troposphere at Dumont d'Urville in 1978, as measured every day by the meteorological station at 0000 GMT. By contrast, in summer, when the sea surface is ice free, the temperature surface inversion is not always present and the whole troposphere can be considered as well-mixed for such cosmonuclides as are studied here. Although these two kinds of situations are actually not well separated, both lower cosmonuclides concentrations, and upper activity ratios $\mathrm{Be}-7 / \mathrm{P}-32$ observed in winter near the ground at Dumont d'Urville, can be explained as follows: as the air at ground level is less frequently renewed, Be-7 and P-32 concentrations are lower (due to scavenging and disintegration processes over a longer time). Moreover, P-32 decreases faster than $\mathrm{Be}-7$ by radioactivity and, consequently, the ratio Be-7/P-32 increases. In effect, we can point out, in Table 1 , that the activity ratio $\mathrm{Be}-7 / \mathrm{P}-32$ reaches, or sometimes exceeds, the production rate ratio 100 in the depth of the Antarctic winter (June and July 1978 and June 1980).

Since Be- 7 and P-32 are produced by the same process and with the same space distribution, it is quite likely that they should be carried by the same aerosols species, and that they should have the same scavenging time in the troposphere. The mean scavenging time obtained is about 8.5 days. This value is quite similar to those computed by Lambert et al. (1982) for the long-lived radioactive $\mathrm{Rn}-222$ daughters in the whole troposphere (6.5 days) or in the sole southern hemisphere (9.1 days).

The signification of the tropopause monthly mean height is not clear, because this height varies very rapidly in space and time. In fact, the determination of this parameter is not critical: in January 1978 , a variation of $100 \mathrm{~m}$ on either side of the mean value of $8690 \mathrm{~m}( \pm 1.15 \%)$ altered the computed flux by $\pm 2 \%$ and the scavenging time by $\mp 4 \%$. Cosmonuclide mean concentration errors are more critical: $\pm 7.5 \%$ variations of one of the cosmonuclide concentrations alter the computed flux by $\pm 35 \%$ and the scavenging time by $\mp 15 \%$. Cosmonuclide production rates are expected to closely follow the changes of cosmic ray intensity, especially at polar geomagnetic latitudes. Data from Lal and Peters (1967) refer to a maximum of solar activity (1948-1949 sunspot numbers 136.3 and 134.7). The period $1978-1980$ is also near a maximum of solar activity (sunspot numbers 90.1 , 


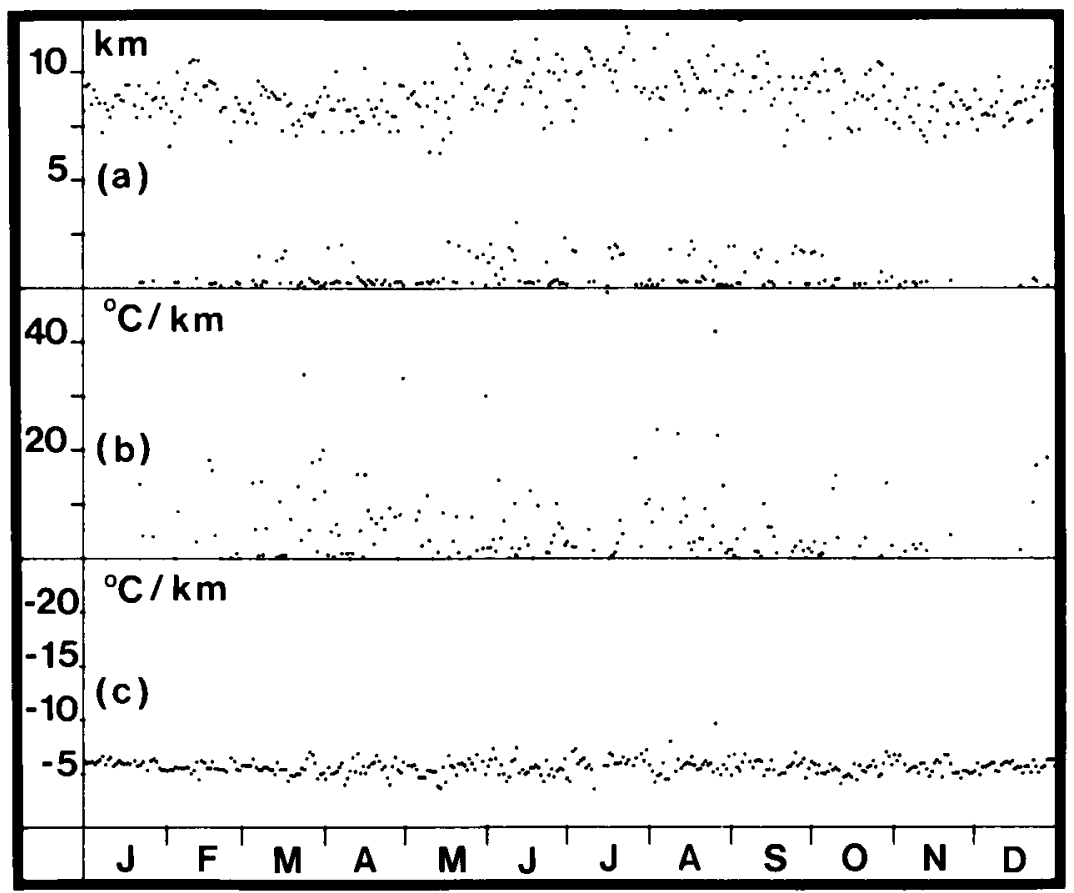

Fig. 4. Meteorological data at Dumont d'Urville. (a) Tropopause height and depth of the temperature inversion layer. (b) Mean temperature gradient in the inversion layer. (c) Mean temperature gradient between the top of the inversion layer and the tropopause.

155.4 and 154.6) and not very different from the 1948-1949 values. Therefore, the actual $\mathrm{Be}-7$ and P-32 production rates might have varied on either side of the values we used, but to a small extent which was neglected here.

In summer, when the temperature surface inversion does not disturb the air mixing at ground level, the mean air exchange rate across the tropopause is found to be of the order of $40 \mathrm{~kg} \mathrm{~m}^{-2}$ day $^{-1}$ ( 8 to $61 \mathrm{~kg} \mathrm{~m}^{-2} \mathrm{day}^{-1}$ ). In January 1978, this air exchange rate was $50 \mathrm{~kg} \mathrm{~m}^{-2}$ day $^{-1}$, which corresponds, at the tropopause altitude, to a layer of about $100 \mathrm{~m}$ thick. During this month, the altitude of the tropopause, at $0000 \mathrm{GMT}$, was varying between 7200 and $9480 \mathrm{~m}$ (mean altitude $8700 \mathrm{~m}$ ), with a mean daily shift of $650 \mathrm{~m}$ from one sounding to another. Such altitude variations could explain a large part of the daily mean exchange rate computed here through the layer, where the tropopause goes up and down, and where the lower stratospheric air mixes with the upper tropospheric air.
Although the tropopause level varies with the season, no seasonal effect can be observed in the daily variations on both sides of the mean altitude. Moreover the temperature gradient in the free troposphere (above the temperature surface inversion) is nearly constant. Consequently, it seems that air exchange flux through the tropopause due to any variations in tropopause height alone, should not vary appreciably during the year. But other mechanisms, which could be affected by seasonal variations, might come into play, such as massive and discontinuous air injections through the tropopause above Antarctica (Robinson et al., 1983) or at middle latitudes (Danielsen, 1964). Our work did not enable us to show seasonal variations and to differentiate between quasi-continuous and discontinuous processes.

Using natural radionuclides $\mathrm{Rn}-222$ and its long-lived daughters $\mathrm{Pb}-210, \mathrm{Bi}-210$ and $\mathrm{Po}-210$ in a two-box model, Lambert et al. (1982) computed the mean annual air flux exchanged across the whole tropopause: 12 to $25 \mathrm{~kg} \mathrm{~m}^{-2}$ day ${ }^{-1}$, i.e. two 
or three times less than the mean value computed here for the Antarctic area. This difference cannot be attributed only to a seasonal local effect. Indeed, if the mean annual value of the exchanges were everywhere about the same, the mean winter value over Antarctica should be very small, nearly zero. Owing to the height values observed in summer in the troposphere, cosmonuclide sources in winter should therefore be reduced to the local production. i.e., in the case of $\mathrm{Be}-7,3$ times less than during the summer. Combined with the effect of the temperature surface inversion, this should reduce still more the $\mathrm{Be}-7$ ground-level concentrations. while the actual seasonal variation is only a factor of 1.5 or 2. Thus, Antarctica seems to be effectively an area where the stratosphere-troposphere exchanges are particularly strong. The summer stratospheric component of $\mathrm{Be}-7$, i.e. the ratio of Be-7 from stratospheric origin/total $\mathrm{Be}-7$ is about $61 \%$ (27 to $75 \%)$, while the P-32 fraction is only about $31 \%$ ( 9 to $44 \%$ ). This high proportion of stratospheric $\mathrm{Be}-7$ in the Antarctic troposphere enables us to use this nuclide as a tracer of stratosphere-to-troposphere injections.

\section{Acknowledgements}

The help of F. Slabodsky, of the "Terres Australes et Antarctiques Françaises" and of the logistic support of the "Expeditions Polaires Françaises" for the setting up and the work of our laboratory at Dumont d'Urville is gratefully acknowledged.

\section{REFERENCES}

Bhandari. N.. Lal, D. and Rama, A. 1966. Stratospheric circulation studies based on natural and artificial radioactive tracer elements. Tellus 18.391-406.

Danielsen, E. F. 1964. Report on Project Springfield. DASA 1517. Headquarters. Defense Atomic Support Agency, Washington D.C. 20301 . July 1984.

Feely, H. W., Toonkel, L. E. and Larsen, R. J. 1980. Radionuclides and trace metals in surface air EML 370, 2, 4-24. Environmental Measurements Laboratory, Department of Energy. New York 10014. USA.

Hogan. A.. Barnard, S., Samson, J. and Winters, W. 1982. The transport of heat. water vapor and particulate material to the south polar plateau. $J$. Geophys. Res. 87. 4287-4292.

Lal, D. and Peters, B. 1962. Cosmic ray produced isotopes and their application to problems in geophysics. In: Progress in cosmic ray physics and elementary particle physics. 6, 1-74. Amsterdam, North-Holland Publ. Co.. 1962.

Lal, D. and Peters. B. 1967. Cosmic ray produced radioactivity on the earth. In: Handbuch der Physik, 46. 551-612, Springer Verlag. Berlin, 1967.

Lambert. G.. Labeyrie. J. and Ardouin. B. 1965. On the existence of a zonal structure of the lower atmosphere. especially in the southern hemisphere (in French). C. R. Acad. Sci. Paris 261, 3857-3860.
Lambert. G., Polian, G., Sanak, J., Ardouin. B., Buisson. A., Jegou, A. and Le Roulley, J. C. 1982. Cycle of radon and daughters: application to the study of troposphere-stratosphere exchanges (in French). $A n n$. Geoph!s. 38. 497-531.

Marenco. A. 1974. Use of radioactive elements Be-7. P. 32. $\mathrm{Sr}-90$. Po- 210 and $\mathrm{Pb}-210$ for the study of particulate matter in the troposphere (in French). Thesis, Paul Sabatier University. Toulouse. France.

Polian. G. 1984. Atmospheric transport processes in the southern hemisphere, and global budget of Radon 222. (in French). Thesis, Paris University. Paris. France.

Reiter. R., Munzert, K., Kanter. H. J. and Potzl. K. 1983. Cosmogenic radionuclides and ozone at a mountain station at $3 \mathrm{~km}$ a.s.l. Arch. Meteorol. Geophys. Bioclimatol., Ser. B, 32, 131-160.

Robinson. E., Clark. D. and Cronn. D. R. 1983. Statospheric-tropospheric exchange over Antarctica. Symposium on Polar Meteorology, International Commission on Polar Meteorology. IUGG/IAMAP. Hamburg, FR, 16-18 August 1983.

Sanak, J. 1983. Researches on the origin and transport processes of the Antarctic aerosols (in French). Thesis, University of Picardie, Saint Quentin. France.

Trenberth, K. E. 1981. Observed southern hemisphere eddy statistics at $500 \mathrm{mb}$ : frequency and spatial dependence. J. Atmos. Sci. 38. 2585-2605. 